\title{
Ecological succession of benthic organisms on niche-type artificial reefs
}

\author{
María-Isabel Toledo* Đi Pamela Torres, Cristina Díaz, Victor Zamora, Jesús López and Germán Olivares
}

\begin{abstract}
As part of efforts to restore fishery resources and recover damaged coastal ecosystems, artificial reefs are often anchored on the seafloor in coastal zones, to provide new habitats for marine organisms. The aim of the study was to describe the structure of a community of benthic invertebrates colonising a niche-type artificial reef (AATN in Spanish). Nine structures were anchored at depths of $16 \pm 1.5 \mathrm{~m}$ for 99 weeks (22 months) in the Area of Benthic Resource Management and Exploitation (AMERB) in coastal waters of the Region of Bio Bio, Chile.

The results showed that, at 3 months from submersion of the NTAR, much of the artificial substrate remained bare and there were only low levels of specimens of Balanus sp. barnacles, showing mean coverage of $11.26 \%$, and even lower proportions of Rhodophyta, with mean coverage of $0.34 \%$. At 6 months, the presence of hydrozoans was seen, decreasing the coverage of the barnacles, which was aided further at 8 months with the arrival of barnacle predatory invertebrates. At 8 months, new benthic invertebrates appeared and competed for the substrate. These included sponges and algae. At 99 weeks, the hydrozoans dominated the substrate, followed by barnacles and Rhodophyta, the first colonising organisms, leading to colonisation by motile macro-invertebrates, mainly consisting of crustaceans, echinoderms and molluscs.

The AATN artificial system provides an ideal substrate for the development of early ecological succession and the use of this technology should be feasible in the recovery process of habitat damaged by anthropogenic actions and climate change.
\end{abstract}

Keywords: Artificial reefs, Ecological succession, Colonisation, Benthic organisms, Balanus sp., Rhodophyta, Hydrozoans

\section{Introduction}

The definitions of artificial reefs vary by country and region, leading the London Convention and Protocol/ UNEP, 2010, to agree the definition that they are structures placed intentionally on the sea bed with the aim of imitating the function of a natural reef, i.e. protection, regeneration, concentration or growth of marine resources. Over the years, artificial reefs have been used for different purposes. The first artificial reefs were built to increase the populations of certain species and thereby increase fishing of those species (Herbert et al. 2017, Noh et al. 2017, Ponti et al. 2015, Fabi et al. 2011).

\footnotetext{
* Correspondence: isabel.toledo@pucv.cl

Escuela de Ciencias del Mar, Facultad de Ciencias del Mar y Geografía, Pontificia Universidad Católica de Valparaíso, Valparaíso, Chile
}

In recent years, artificial reefs have being used to recover and repair habitats damaged by anthropogenic intervention or climate changes (Komyakova et al. 2019, Lee et al. 2018, Silva Lima et al. 2018).

Over time, these reefs have become more popular and their aims have subsequently broadened (Ponti et al., 2015, Fabi et al., 2011) to account for new needs, such as recreation, habitat restoration or growth, contribution of new knowledge on species behaviour in its natural habitat or beach protection and erosion control (Encarnação \& Calado, 2018, González-Duarte et al. 2018, Herbert et al. 2017, Liu et al. 2017, Navarro-Barranco et al. 2015, Firth et al. 2014, Pacheco et al. 2011, Ponti et al. 2015, Perkol-Finkel \& Benayahu 2005). This has led to increased knowledge regarding the materials used to build such structures, ensuring they are not damaging to 
the environment (Herbert et al. 2017, Liversage et al. 2017, Spagnolo et al. 2014, Ponti et al. 2015, Fabi et al. 2011, OSPAR Commission 2009, Perkol-Finkel \& Benayahu 2005) and achieving more adequate designs and sizes in accordance with the purpose in question (Lavender et al. 2017, Rosental Zalmon et al. 2014, Perkol-Finkel \& Benayahu 2005). Waste materials were generally used, such as tyres, wrecked ships, or the remains of machines, research platforms and pipes (Meyer et al. 2017, Ponti et al. 2015, Perkol-Finkel \& Benayahu 2005). Today, the more common materials are concrete, pebbles, limestone rocks and in many cases PVC (Lezzi et al. 2018, Liversage et al. 2017, Vaz-Pinto et al. 2014).

One of the main studies carried out after installing an artificial reef is into the process of ecological succession by benthic organisms that colonise the structure (González-Duarte et al. 2018, Herbert et al. 2017, Lezzi et al. 2018, Navarro-Barranco et al. 2015, Sen et al. 2014, Uribe et al. 2015, Perkol-Finkel \& Benayahu 2005). Several studies suggest that during ecological succession in marine environments on this type of structure, the stages of succession can be identified based on the pattern of development of the communities that settle on the surface (Balqadi et al. 2018, Liu et al. 2017, Vergara et al. 2016, Lozano-Cortés \& Zapata 2014, Salta et al. 2013, Sweet et al. 2011, Keough 1998).

Ecological succession is defined in general as the perturbation of a specific area leading to changes in habitat and community, occurring either naturally or by human action (Herbert et al. 2017, Uribe et al. 2015, Vas-Pinto 2014). Several studies suggest that different stages can be identified in the process based on the development of communities settling on the surface (Balqadi et al. 2018, Liu et al. 2017, Vergara et al. 2016, Lozano-Cortés \& Zapata 2014, Salta et al. 2013, Sweet et al. 2011, Keough 1998). These stages are early succession and late succession (Herbert et al. 2017, Lezzi et al. 2018, Meyer et al. 2017, Sen et al. 2014, Vas-Pinto 2014, Pacheco et al. 2011). Early succession is associated with the first organisms that settle on the reef, including the appearance of organised microorganisms such as microbial mats or biofilm (Herbert et al. 2018, Balqadi et al. 2018, LozanoCortés \& Zapata 2014, Pacheco et al. 2011, Perkol-Finkel \& Benayahu 2005). This is followed by the arrival of more complex organisms, which in turn attract predator species from further along the food chain, thus establishing a new community in the habitat; this stage is known as late succession (Herbert et al. 2017).

The aim of this study is to evaluate the ecological succession of benthic organisms, assessing the association between time and the variables measured, as well the similarity in species composition between monitoring dates. The results will help us to define if the artificial reef system of the niche-type NTAR (AATN in Spanish), once installed on the seabed, provides an alternative substrate for the development of a community, whose community structure might present an ecological process. This objective will be achieved by monitoring the colonisation process of sessile and mobile organisms that setthe in artificial structures over a period of 99 weeks (22 months).

\section{Materials and methods}

\section{Description of a niche-type artificial reef (NTAR) and the study site}

The NTAR is an almost pyramid structure with a height to width measurement of $90-160 \mathrm{~cm}$ composed of 42 cavities and made from high resistance marine concrete (Fig. 1). The design was created to favour settlement of coastal fish species and benthic resources (Toledo et al. 2017). Nine of these structures were sunk randomly in order to form a niche artificial reef system (Fig. 2). They were submerged in September 2016 at depths of $16 \pm$ $1.5 \mathrm{~m}$ in an Area of Benthic Resource Management and Exploitation, AMERB-Lebu, in the Region of Bio Bio in Chile.

\section{Data collection}

The focus used in the study was on non-invasive data collection, involving taking undersea photographs and video recordings. The aim is to avoid altering the natural development process of the community of invertebrates and macroalgae in the niche artificial system, thus decreasing the availability of food. However, the potential limitations of this method can lead to difficulty in recognising species taxonomy and low image quality due to the constant high level of turbidity in the area. As a result, it is possible to under or overestimate population levels and coverage, with little probability of recording smaller species or ones with more hidden habitats. Due to these limitations, the benthic organisms settled on the niche artificial system were studied on seven occasions,

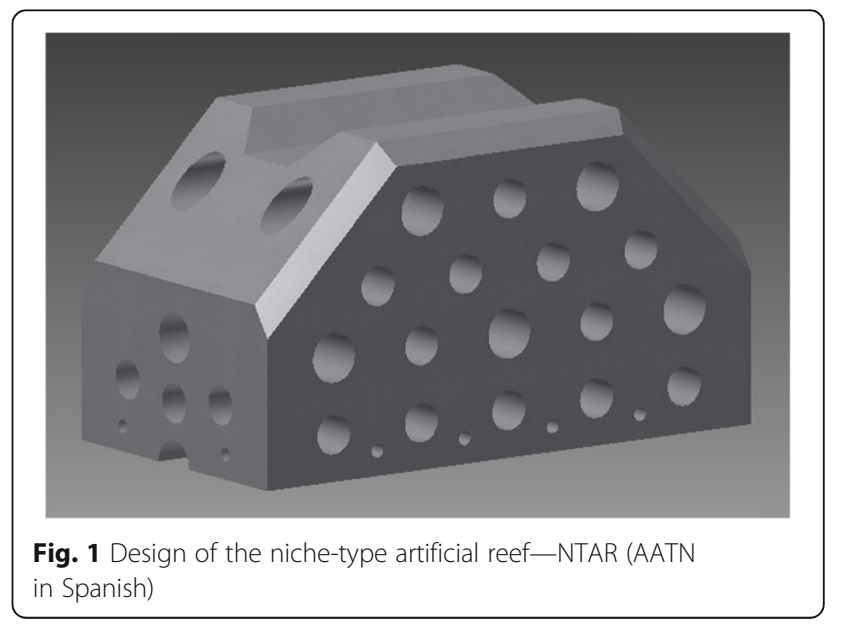




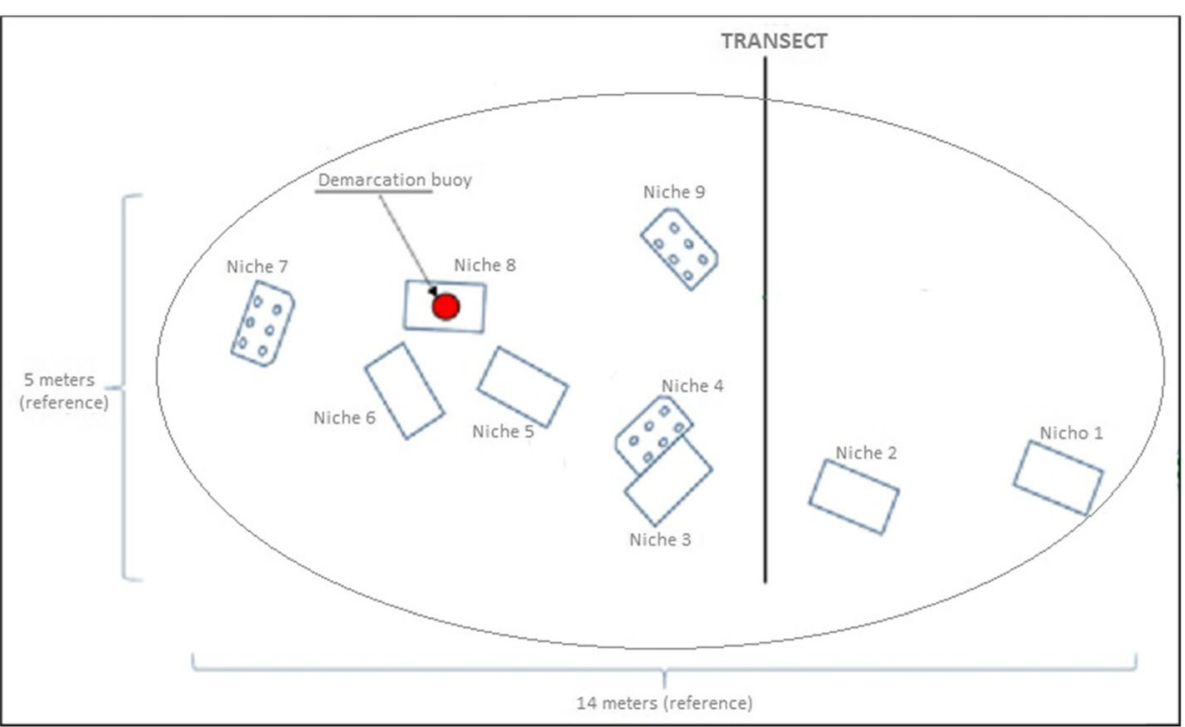

Fig. 2 Scheme of the location of the niche-type artificial reef-NTAR system: arrangement and approximated distances

from December 2016 to August 2018. The data gathering was carried out by undersea video recording in movement, between the structures, in order to capture the highest number of motile and sessile benthic organisms living on the NTAR. The video files were then reviewed in the laboratory, with the help of available literature on the study area and the key taxonomies (Zúñiga 2002a, Zúñiga 2002b, Tapia 2002, Zagal \& Hermosilla 2007).

The undersea filming consisted of placing 18 points at random over the NTAR and photographing the point using the photo-quadrat method (Foster et al. 1991) with a quadrat of $40 \times 40 \mathrm{~cm}$ around a GoPro Hero Black Adventure digital camera. For cases in which it was not possible to photograph all the quadrats, they were removed from the recording. Each photo was analysed using the software Coral Point Count with excel extensions. Percentage coverage was quantified by projecting 100 points uniformly on each photo and assigning a value of $1 \%$ to each sessile organism present at a single point. In order to quantify abundance, the total number of individuals was counted in each quadrat.

\section{Data analysis-description of ecological succession}

The percentages were transformed with the arcsine function to stabilise the variance. Confidence intervals of $95 \%$ for coverage and abundance data were calculated using the Student $t$ test, based on the method described by Zar 1999. Ecological indices were estimated using the average coverage data over the monitoring time: Shannon diversity index $H^{\prime}$ (Shannon 1948); Margalef species richness index, $d$ (Margalef 1958); Pielou's uniformity index, $J$ (Pielou 1975) and Simpson's dominance index
(1949). Kendall's Tau correlation analysis was conducted to explore the correlation between time, species abundance and the ecological indices (Kendall 1955). In order to avoid underestimation of fractional average values, all data values were multiplied by a factor to make them whole numbers, maintaining their proportion. Calculations of the ecological indices were carried out in the Past software, version 3.15 .

In order to compare the similarity of the species settled on the niche artificial system over the seven monitoring sessions, multivariate analysis was conducted using the Primer-E 5 version 5.2.9 program. The coverage and abundance information were treated separately. To visualise the spatial changes in species composition between monitoring dates, non-metric multidimensional scaling (NMDS) was applied using the Bray-Curtis index, transforming the abundance data with $\log (x+1)$. Oneway ANOSIM was used to test for significant changes in the structure of the community over time. The proportions of each taxonomic group in the differences in community structure over time were analysed using the SIMPER test.

\section{Results}

Three months after submersion of the structures, a large area of bare substrate was still observable. The organisms that could be identified were Balanus sp. barnacles, presenting a type $r$ colonisation strategy, and the polychaete Phragmatopoma virgini with mean coverage of $56.20 \%$ and $3.54 \%$, respectively. The presence of biofilm was also seen at this first monitoring date, with a mean coverage of $36.41 \%$ (Table 1). Motile organisms were not seen within the quadrats. 
Table 1 Mean coverage and confidence intervals (Cl) at 95\% for sessile organisms present on the niche artificial reefs

\begin{tabular}{|c|c|c|c|c|c|c|c|c|}
\hline \multicolumn{9}{|c|}{ Organism coverage (\%) } \\
\hline & Biofilm & $\begin{array}{l}\text { Indet } \\
\text { Hydrozoa }\end{array}$ & Balanus sp. & Callophyllis sp. & $\begin{array}{l}\text { Lithothamnion } \\
\text { sp. }\end{array}$ & $\begin{array}{l}\text { Indet } \\
\text { Demospongiae } 1\end{array}$ & $\begin{array}{l}\text { Indet } \\
\text { Demospongiae } 2\end{array}$ & $\begin{array}{l}\text { Phragmatopoma } \\
\text { virgini }\end{array}$ \\
\hline Monitoring & $\begin{array}{l}X \pm S D \\
(I C 95 \%)\end{array}$ & $\begin{array}{l}X \pm S D \\
(C \mid 95 \%)\end{array}$ & $\begin{array}{l}X \pm S D \\
(C I 95 \%)\end{array}$ & $\begin{array}{l}X \pm S D \\
(C I 95 \%)\end{array}$ & $\begin{array}{l}X \pm S D \\
(C I 95 \%)\end{array}$ & $\begin{array}{l}X \pm S D \\
(C \mid 95 \%)\end{array}$ & $\begin{array}{l}X \pm S D \\
(C \mid 95 \%)\end{array}$ & $\begin{array}{l}X \pm S D \\
(C I 95 \%)\end{array}$ \\
\hline 1 & $\begin{array}{l}36.41 \pm 17.91 \\
(17.41-57.94)\end{array}$ & - & $\begin{array}{l}56.20 \pm 21.75 \\
(32.47-78.51)\end{array}$ & - & - & - & - & $\begin{array}{l}3.54 \pm 3.19 \\
(1-7.56)\end{array}$ \\
\hline 2 & $\begin{array}{l}0.31 \pm 0.07 \\
(0.19-0.47)\end{array}$ & $\begin{array}{l}24.08 \pm 6.87 \\
(13.83-36.12)\end{array}$ & $\begin{array}{l}45.52 \pm 5.11 \\
(34.43-56.83)\end{array}$ & $\begin{array}{l}10.94 \pm 1.41 \\
(7.52-14.91)\end{array}$ & - & $\begin{array}{l}0.32 \pm 0.04 \\
(0.22-0.44)\end{array}$ & $\begin{array}{l}0.36 \pm 0.18 \\
(0.15-0.65)\end{array}$ & $\begin{array}{l}11.61 \pm 3.06 \\
(6.63-17.77)\end{array}$ \\
\hline 3 & $\begin{array}{l}0.29 \pm 0.03 \\
(0.21-0.39)\end{array}$ & $\begin{array}{l}61.32 \pm 1.79 \\
(54.73-67.70)\end{array}$ & $\begin{array}{l}11.67 \pm 5.77 \\
(5.11-20.45)\end{array}$ & $\begin{array}{l}17.55 \pm 3.39 \\
(11.13-25.06)\end{array}$ & $\begin{array}{l}0.29 \pm 0.03 \\
(0.21-0.40)\end{array}$ & $\begin{array}{l}0.82 \pm 0.95 \\
(0.18-1.93)\end{array}$ & $\begin{array}{l}0.37 \pm 0.07 \\
(0.23-0.54)\end{array}$ & $\begin{array}{l}1.09 \pm 1.24 \\
(0.24-2.54)\end{array}$ \\
\hline 4 & - & $\begin{array}{l}57.63 \pm 1.48 \\
(51.59-63-55)\end{array}$ & $\begin{array}{l}23.65 \pm 3.75 \\
(15.96-32.33)\end{array}$ & $\begin{array}{l}12.59 \pm 4.73 \\
(6.30-20.66)\end{array}$ & - & $\begin{array}{l}0.94 \pm 0.87 \\
(0.26-2.05)\end{array}$ & - & $\begin{array}{l}0.33 \pm 0.09 \\
(0.18-0.53)\end{array}$ \\
\hline 5 & - & $\begin{array}{l}52.5 \pm 2.47 \\
(44.65-60.28)\end{array}$ & $\begin{array}{l}33.69 \pm 3.60 \\
(25.06-42.91)\end{array}$ & $\begin{array}{l}4.46 \pm 3.13 \\
(1.54-8.81)\end{array}$ & $\begin{array}{l}0.80 \pm 0.94 \\
(0.17-1.88)\end{array}$ & $\begin{array}{l}0.32 \pm 0.07 \\
(0.18-0.49)\end{array}$ & $\begin{array}{l}0.43 \pm 0.16 \\
(0.21-0.73)\end{array}$ & $\begin{array}{l}1.92 \pm 1.41 \\
(0.64-3.88)\end{array}$ \\
\hline 6 & - & $\begin{array}{l}44.92 \pm 6.45 \\
(32.52-57.64)\end{array}$ & $\begin{array}{l}9.27 \pm 2.97 \\
(4.90-14.85)\end{array}$ & $\begin{array}{l}37.55 \pm 9.28 \\
(23.46-52.81)\end{array}$ & $\begin{array}{l}1.18 \pm 1.01 \\
(0.34-2.50)\end{array}$ & $\begin{array}{l}0.39 \pm 0.09 \\
(0.22-0.61)\end{array}$ & $\begin{array}{l}0.36 \pm 0.05 \\
(0.24-0.51)\end{array}$ & $\begin{array}{l}0.41 \pm 0.23 \\
(0.16-0.77)\end{array}$ \\
\hline 7 & - & $\begin{array}{l}67.43 \pm 2.51 \\
(59.83-74.60)\end{array}$ & $\begin{array}{l}2.85 \pm 1.29 \\
(1.27-5.04)\end{array}$ & $\begin{array}{l}1.72 \pm 3.53 \\
(0.14-5.01)\end{array}$ & $\begin{array}{l}2.74 \pm 3.03 \\
(0.63-6.29)\end{array}$ & $\begin{array}{l}11.29 \pm 2.61 \\
(6.71-16.88)\end{array}$ & - & $\begin{array}{l}5.04 \pm 1.84 \\
(2.50-8.40)\end{array}$ \\
\hline
\end{tabular}

$X=$ mean, $S D$ standard deviation, $-=$ not observed

At 6 months, the availability of bare substrate had decreased dramatically, with new organisms seen settling on the structures, in addition to the ones identified previously. The community was dominated again by Balanus sp., with mean coverage of $45.52 \%$, a slight decrease in comparison to the first monitoring. Phragmatopoma virgini showed a small increase in coverage, reaching $11.61 \%$. The new organisms identified were indeterminate hydrozoans, Callophyllis sp. of algae and two sponges defined as indeterminate Demospongiae class 1 and 2. Of these the biggest impact was presented by the hydrozoans, with coverage of $24.08 \%$ of the structure. Biofilm decreased its coverage significantly, dropping to less than $1 \%$ due to the increase of organisms colonising the substrate (Table 1). During this second monitoring, the presence of motile fauna was also observed, such as individuals of the Argobuccinum sp., a predatory snail, with an average density of 0.72 ind $/ 0.16 \mathrm{~m}^{2}$, the sea stars Meyenaster gelatinosus and Odontaster penicilatus, both with low mean density of 0.06 ind $/ 0.16 \mathrm{~m}^{2}$ (Table 2).

At 8 months, during the third monitoring session, the most substantial changes were observed. This included

Table 2 Mean abundance and confidence intervals (Cl) at 95\% for motile organisms and ichthyofauna present on the niche artificial reefs

\begin{tabular}{|c|c|c|c|c|c|c|c|c|}
\hline \multicolumn{9}{|c|}{ Organism density (ind/0.16 $\mathrm{m}^{2}$ ) } \\
\hline & $\begin{array}{l}\text { Cancer } \\
\text { edwardsii }\end{array}$ & $\begin{array}{l}\text { Argobuccinum } \\
\text { sp. }\end{array}$ & $\begin{array}{l}\text { Henricia } \\
\text { obesa }\end{array}$ & $\begin{array}{l}\text { Meyenaster } \\
\text { gelatinosus }\end{array}$ & Tégula sp. & $\begin{array}{l}\text { Concholepas } \\
\text { concholepas }\end{array}$ & $\begin{array}{l}\text { Indet } \\
\text { decapodas }\end{array}$ & $\begin{array}{l}\text { Odontaster } \\
\text { penicilatus }\end{array}$ \\
\hline Monitoring & $\begin{array}{l}X \pm S D \\
(C I 95 \%)\end{array}$ & $\begin{array}{l}X \pm S D \\
(C \mid 95 \%)\end{array}$ & $\begin{array}{l}X \pm S D \\
(C \mid 95 \%)\end{array}$ & $\begin{array}{l}X \pm S D \\
(C \mid 95 \%)\end{array}$ & $\begin{array}{l}X \pm S D \\
(C I 95 \%)\end{array}$ & $\begin{array}{l}X \pm S D \\
(C \mid 95 \%)\end{array}$ & $\begin{array}{l}X \pm S D \\
(C I 95 \%)\end{array}$ & $\begin{array}{l}X \pm S D \\
(C I 95 \%)\end{array}$ \\
\hline 1 & - & - & - & - & - & - & - & - \\
\hline 2 & - & $\begin{array}{l}0.72 \pm 1.49 \\
(-0.37-1.81)\end{array}$ & - & $\begin{array}{l}0.06 \pm 0.24 \\
(-0.28-0.40)\end{array}$ & - & - & - & $\begin{array}{l}0.06 \pm 0.24 \\
(-0.62-0.73)\end{array}$ \\
\hline 3 & - & $\begin{array}{l}1.44 \pm 1.69 \\
(0.21-2.68)\end{array}$ & - & - & - & - & - & - \\
\hline 4 & - & $\begin{array}{l}0.39 \pm 0.70 \\
(-0.12-0.90)\end{array}$ & - & - & $\begin{array}{l}0.06 \pm 0.24 \\
(-0.34-0.45)\end{array}$ & - & - & - \\
\hline 5 & $\begin{array}{l}0.06 \pm 0.24 \\
(-0.06-0.17)\end{array}$ & $\begin{array}{l}0.72 \pm 1.18 \\
(-0.14-1.59)\end{array}$ & - & - & $\begin{array}{l}0.17 \pm 0.38 \\
(-0.48-0.81)\end{array}$ & - & - & - \\
\hline 6 & - & $\begin{array}{l}0.33 \pm 0.59 \\
(-0.10-0.77)\end{array}$ & - & $\begin{array}{l}0.06 \pm 0.24 \\
(-0.28-0.40)\end{array}$ & $\begin{array}{l}0.06 \pm 0.24 \\
(-0.34-0.45)\end{array}$ & $\begin{array}{l}0.11 \pm 0.32 \\
(-0.51-0.73)\end{array}$ & $\begin{array}{l}0.06 \pm 0.24 \\
(-0.45-0.56)\end{array}$ & - \\
\hline 7 & - & $\begin{array}{l}0.17 \pm 0.51 \\
(-0.21-0.54)\end{array}$ & $\begin{array}{l}0.22 \pm 0.55 \\
(-0.44-0.88)\end{array}$ & - & $\begin{array}{l}0.17 \pm 0.38 \\
(-0.48-0.81)\end{array}$ & - & - & - \\
\hline
\end{tabular}


the abrupt drop in Balanus sp., going from coverage of almost half the structure to only $11.67 \%$, and being replaced by indeterminate hydrozoans, which now showed coverage of $61.32 \%$, almost threefold the level at the previous monitoring. Other organisms showed slight increases in mean coverage, except for the biofilm, which continued to decrease. The algae Lithothamnion sp. was also identified, with a coverage percentage of $0.29 \%$ (Table 1). There was continued presence of Argobuccinum sp., with a slight increase in density to 1.44 ind/ $0.16 \mathrm{~m}^{2}$, in addition to the arrival of representative of the Actinopterygii class, with density of 0.06 ind $/ 0.16 \mathrm{~m}^{2}$ (Table 2).

For the fourth monitoring date, at 10 months, the community showed another change, with the disappearance of species such as Lithothamnion sp. and indeterminate Demospongiae. Indeterminate hydrozoans continued to dominate the substrate, though their coverage fell slightly and that of Balanus sp. increased. There were slight variations in other organisms, some increasing while others decreased their coverage (Table 1). As of this monitoring, the biofilm had disappeared completely from the substrate (Table 1). For the motile organisms, in addition to the presence of Argobuccinum sp. (whose density fell somewhat), there was a new arrival of Tegula sp. snail, with a low density of 0.06 ind/ $0.16 \mathrm{~m}^{2}$ (Table 2).

Twenty days later, the fifth monitoring session was conducted. It was seen that the Balanus sp. and the indeterminate hydrozoans were competing directly for available substrate, and that the barnacle had slightly increased its coverage, while the coverage of hydrozoans had decreased by a similar proportion (Table 1). There was a return of organisms that had disappeared from the previous monitoring, with a higher coverage percentage than when last seen. There was a slight increase in the diversity of motile fauna. Argobuccinum sp. continued to dominate this category with a mean density of 0.72 ind/ $0.16 \mathrm{~m}^{2}$, Tégula sp. increased slightly to 0.17 ind/0.16 $\mathrm{m}^{2}$, while a new organism was seen, representing the crustaceans, Cancer edwardsii, with a mean density of $0.06 \mathrm{ind} / 0.16 \mathrm{~m}^{2}$ (Table 2).

During the sixth monitoring session, 15 months after installation of the NTAR, the dynamics of the community continued to vary. The indeterminate hydrozoans remained the dominant organism, with their direct competitor, Balanus sp., seeing a drastic decrease in coverage, reaching only 9.27\%, while Callophyllis sp. significantly increased coverage, reaching almost $40 \%$ (Table 1). The other organisms saw only small fluctuations in coverage. Though it saw a decrease in density, Argobuccinum sp. remained the dominant organism in the motile fauna category, with 0.33 ind $/ 0.16 \mathrm{~m}^{2}$. This was followed by Concholepas concholepas with a mean density of 0.11 ind $/ 0.16 \mathrm{~m}^{2}$, while Meyenaster gelatinosus, Tégula sp. and indeterminate decapods all showed densities around $0.06 \mathrm{ind} / 0.16 \mathrm{~m}^{2}$ (Table 2).

Finally, at the seventh monitoring at 99th week, the community remained dominated by indeterminate hydrozoan species, with a considerable increase in coverage, reaching almost 70\%, while Balanus sp. and Callophyllis sp., their direct competitors, fell to less than 3\% and $2 \%$, respectively. A significant increase was seen in Demospongiae 1, which had remained below $1 \%$ at all other monitoring dates, and on this occasion rose to $11.29 \%$ (Table 1). In the category of motile fauna, the presence of Argobuccinum sp. fell, averaging a density of $0.17 \mathrm{ind} / 0.16 \mathrm{~m}^{2}$, as did the density of Tégula sp., leaving the sea star Henricia obesa as the dominant organism, with a density slightly above 0.22 ind $/ 0.16 \mathrm{~m}^{2}$, though it was only seen during this last monitoring session.

The results of the analysis of the ecological indices $\left(H^{\prime}, J, d\right.$ and $\left.D\right)$ show that the community has a low level of diversity (Fig. 3), with a temporary increase in the second monitoring session, which in turn coincides with the multivariate analysis (Fig. 4 and Table 3). Here, the ecological succession is divided into three stages, the second stage of which begins with monitoring 2, with the arrival of new organisms to the system. The Shannon and Pielou indices (Fig. $3 \mathrm{a}$ and b) show a constant level in diversity over time, excluding the increase at monitoring session 2 , which is not significant as the level of diversity remains below what is considered high for both indices. It can also be seen that the Margalef index increases with immersion time (Fig. 3c), showing that the highest level of richness is seen in the last monitoring session. Simpson's dominance index shows a decline in the second monitoring (Fig. 3d), when new organisms being to settle on the structure (Table 1) and a further increase in dominance in the third monitoring due to the presence of indeterminate hydrozoans, as mentioned in the description of ecological succession.

According to the multidimensional scaling analysis of organism coverage over the 99 weeks of monitoring, the succession process is comprised of 3 phases: phase 1 is the first monitoring session 3 months after the NTAR was installed, phase 2 covers the second to the sixth monitoring dates and phase 3 is the last monitoring session at 99 weeks (Fig. 3). There are data in phase 2 that correspond to phase 3 , since the places where the random sampling was carried out showed conditions similar to those of phase 2. The ANOSIM for the three phases shows that the community structure is significantly affected (ANOSIM $R=0.72, p=0.0001$ ) by immersion time. The coupled analysis indicates that there are significant differences between phases 1, 2 and 3 (Table 3), while the SIMPER analysis shows that the highest 


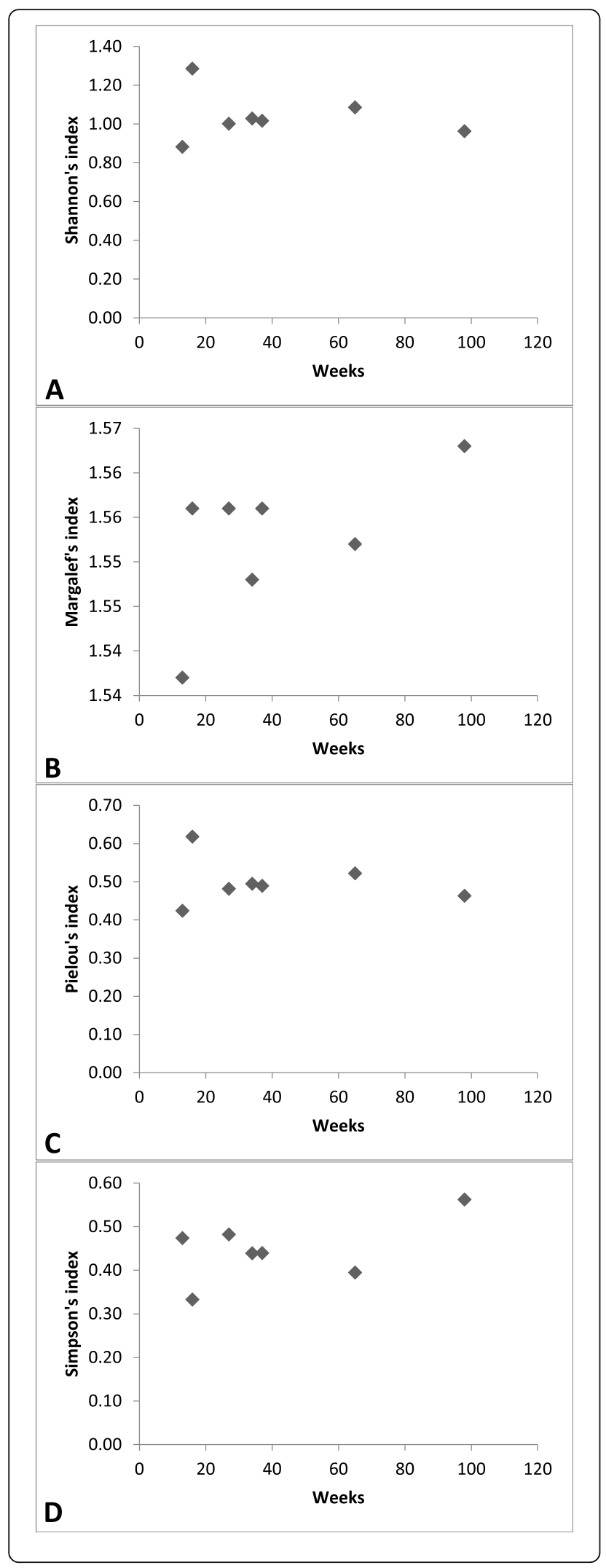

Fig. 3 Variations in diversity (Shannon's diversity (a), Pielou's uniformity (b), Margalef's richness (c) and Simpson's dominance index (d)) for benthic biota associated with the niche artificial reef, over 99 weeks (22 months) monitoring period

contribution to dissimilarity between the three phases results mainly from the indeterminate hydrozoans and the Balanus sp., followed by the biofilm and Callophyllis sp. (Table 3). According to Kendall's Tau correlation (Table 4), the strongest correlation is seen between species richness $(d)$ and abundance $(N)$, in indirect proportion, suggesting that the higher the richness, the lower the abundance, and vice versa. Other variable pairs with strong correlations were time/diversity, time/uniformity, abundance/diversity and abundance/uniformity, though these all maintain a direct correlation, unlike the first example.

\section{Discussion}

At the first monitoring session carried out 3 months after submersion of the niche artificial reef, large amounts of substrate remained available, with only a fine layer of microorganisms, known as biofilm or microfouling. This is common to the first stage in the colonisation process (Balqadi et al. 2018). Biofilm is composed mainly of diatoms and bacteria, surrounded by a matrix of natural polymers secreted by these organisms, to which several different microbes, fungi, algae and detritus also adhere (Salta et al. 2013, Liu et al. 2017). It is expected that these should be the first microorganisms to appear on bare marine substrate, as several researchers have reported this type of colonisation (Lozano-Cortés \& Zapata 2014, Sweet et al. 2011, Keough 1998). The presence of the biofilm layer remained until the eighth month after installation. Its presence during this early stage might induce the settlement of benthic invertebrates and algal spores (Siboni et al. 2007), even determining through specific chemical signals, and what type of invertebrate larvae adhere to the substrate (Freckelton et al. 2017).

According to our results, one of the first colonising species was the barnacle Balanus sp., which dominated for the first 6 months. Its early appearance in the succession of benthic communities and its tendency to dominate the space have been reported previously for artificial structures (Genzano et al. 2018, Lozano-Cortés \& Zapata 2014, Henschel et al. 1990, Brown \& Swearingen 1998). Birkeland (1977) proposes that this behaviour of barnacles is related to their type $r$ life strategy, which is due to their small size, rapid reproduction, early sexual maturity and short generations.

Macroalgae of the Rhodophyta group were also found among the colonising species, which has been observed 


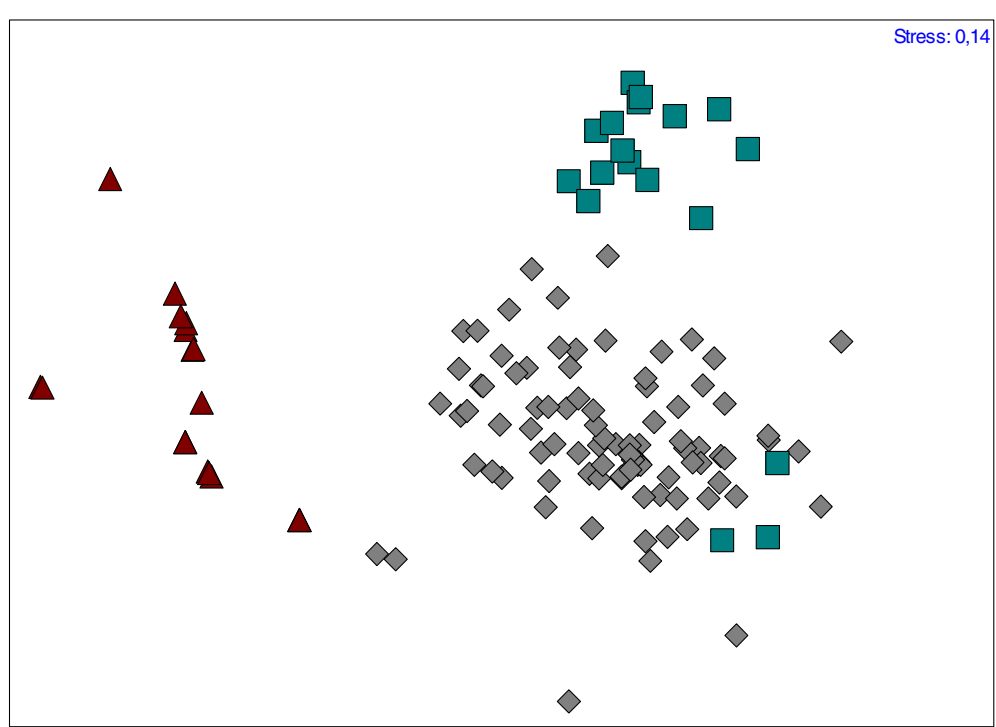

Fig. 4 Community structure in the niche artificial reefs: non-parametric multidimensional scaling of the coverage (arcsine transform), based on the Bray-Curtis similarity index and the $\log (x+1)$ transform, over the 100 weeks monitoring period. $\Delta=$ first monitoring session, $\diamond=$ second to sixth monitoring sessions and $\square=$ seventh monitoring. Stress $=0.14$

Table 3 Similarity analysis and percentage contribution of dissimilarity in the community structure based on organism coverage on the niche artificial reef. Phase $1=13$ weeks, phase $2=15$ to 67 weeks, phase $3=68$ to 99 weeks ( 22 months after installation of the NTAR)

\begin{tabular}{|c|c|c|c|}
\hline \multicolumn{4}{|l|}{ Analysis } \\
\hline \multicolumn{4}{|l|}{ ANOSIM } \\
\hline & \multicolumn{3}{|l|}{$R$ values } \\
\hline & $\begin{array}{l}\text { Phase 1- } \\
\text { phase } 2\end{array}$ & $\begin{array}{l}\text { Phase 1- } \\
\text { phase } 3\end{array}$ & $\begin{array}{l}\text { Phase } 2- \\
\text { phase } 3\end{array}$ \\
\hline & 0.8934 & 0.9542 & 0.5022 \\
\hline & \multicolumn{3}{|c|}{$p$ value $=0.0001$} \\
\hline \multicolumn{4}{|l|}{ SIMPER } \\
\hline & \multicolumn{3}{|c|}{$\%$ contribution } \\
\hline & $\begin{array}{l}\text { Phase 1- } \\
\text { phase } 2\end{array}$ & $\begin{array}{l}\text { Phase 1- } \\
\text { phase } 3\end{array}$ & $\begin{array}{l}\text { Phase } 2- \\
\text { phase } 3\end{array}$ \\
\hline Indet. hydrozoans & 29.61 & 31.60 & 17.16 \\
\hline Biofilm & 24.70 & 20.58 & 0.12 \\
\hline Balanus sp. & 22.21 & 24.89 & 23.55 \\
\hline Callophyllis sp. & 14.55 & 2.69 & 21.52 \\
\hline Phragmatopoma virgini & 6.801 & 6.19 & 11.28 \\
\hline Indet. Demospongiae 2 & 0.93 & 10.17 & 18.07 \\
\hline Lithothamnion sp. & 0.82 & 3.88 & 7.69 \\
\hline Indet. Demospongiae 1 & 0.38 & 0 & 0.59 \\
\hline
\end{tabular}

previously on artificial substrates in Chilean waters by Pacheco et al. (2011), who saw small sporophytes of the red alga Rhodymenia corallina in submerged artificial panels after 3 months and up to the end of the research at 27 months. These researchers also found that the main invertebrate species and algae on their artificial substrate were similar to those present in the natural environment. It is therefore possible to posit that the Rhodophyta algae found on our niche artificial reef are those identified in the forest of red algae in a nearby natural community, i.e. Callophyllis variegata, Rhodymenia sp. and/or Sarcothalia crispata (Vergara et al. 2016).

Regarding the drop in Balanus sp., it should be noted that when counting this taxon, any evidence of the presence of barnacles was included. These traces of barnacles included large whiteish areas of Balanus sp., which

Table 4 Correlation between time, abundance and the ecological indices for the coverage of benthic species

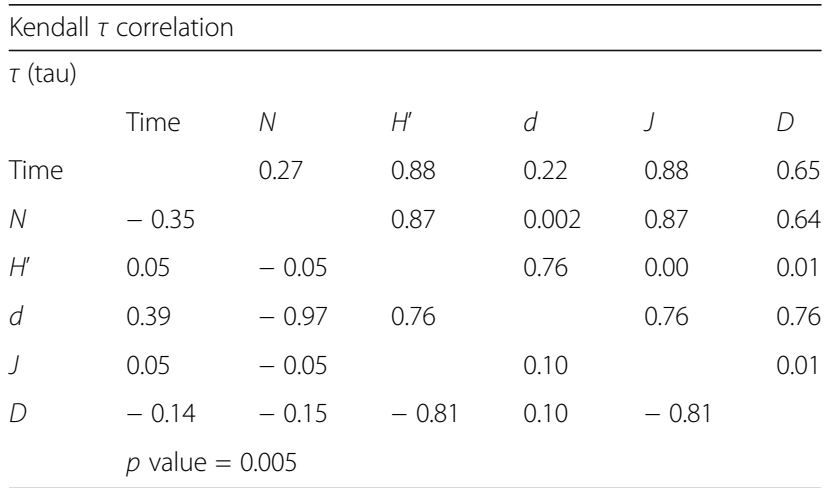

$\tau$ (tau) Kendall coefficient of correlation, $N$ abundance, $d$ Margalef's index, $H^{\prime}$ Shannon's index, J Pielou's index, D Simpson's index 
coincided with the arrival of adult individuals of the gastropod C. concholepas. In this stage in its lifecycle, this species shows a notable preference for feeding on invertebrates of the species Balanus flosculus, Balanus laevis and Pyura chilensis (Castilla et al. 1979), suggesting that the Balanus sp. were likely preyed upon by $C$. concholepas. Whiteish areas were also seen, though to a lesser extent, during the monitoring sessions at 8 and 8.5 months, which may be due to opportunist predatory species such as Argobuccinum sp. and M. gellatinosus (Avila et al. 2012).

Based on the composition of the benthic community, three phases were observed in the succession process corresponding to early colonisation (Carter \& Prekel 2008). This situation was also found in the research by Choi et al. (2019) into alga succession. The analysis of organism coverage gave more clarity to this identification; however, the abundance data did not agree with these results, as it showed significant similarity in its structure and composition during the period. This is because the coverage information corresponds to sessile biota and the abundance information is for motile biota. The results show that during the study period, the organism number of each species varied, i.e. it increased or decreased at each monitoring, while the structure and composition of the community remained similar for all monitoring dates. This is common with new substrates that are beginning a colonisation process from scratch (Martell et al. 2018, Lozano-Cortés \& Zapata 2014, Carter \& Prekel 2008, Beserra et al. 2006, Perkol-Finkel \& Benayahu 2005, Dean \& Connell 1987a).

The sessile biota on the NTAR are the first organisms to settle on the available substrate and they perform the function of increasing the complexity of the habitat, offering refuge and food for the fauna that subsequently colonise the structure and whose presence responds to these factors (Antoniadou et al. 2011, Antoniadou et al. 2010, Dean \& Connell 1987b). It is expected that as the niche artificial system spends more time on the sea floor, the changes induced by the development of sessile biota will offer a better habitat and lead to greater abundance of motile fauna, favouring maturity of the ecosystem, as seen in other studies (Xu et al. 2019, Higgins et al. 2019, Fariñas-Franco \& Roberts 2014, Antoniadou et al. 2010, Dean \& Connell 1987b). It can also be assumed that the presence of the later will be used to identify more clearly a succession pattern that correlates with the coverage of sessile organisms.

The niche-type artificial reef (AATN) was seen to be functional in terms of acting as an alternative substrate for the settlement of benthic invertebrates; this can be seen in the fact that over the 22-month monitoring period, the presence of both sessile and motile communities was found on the structures. A similar performance has been seen with other cement structures installed on the sea floor (Spagnolo et al. 2014, Andersson et al. 2009). Regarding the level of ecological succession, the niche system had not reached full maturity after almost 100 weeks (22 months); however, thanks to the video recordings it was possible to identify the presence of some fishing resources. Despite the low number of species seen on the niche artificial reef, some of them are resources of economic interest to small-scale fishing. These include the Chilean abalone C. concholepas, palo palo snails Argobuccinum sp., the crab Cancer sp., the alga Carola Callophyllis sp., kelp crab Taliepus sp., Chilean stone crab Homalaspis plana and the rock prawn Rhynchocinetes typus (National Fisheries and Aquaculture Service 2017).

\section{Conclusions}

The presence of the resources observed in the succession process suggests that the artificial reef of the niche type, once installed on the seabed, provides an alternative substrate for the development of a community of benthic organisms. It is expected that, in the medium term, their populations will increase as available food sources increase, thus fulfilling the expectation of the new technology that is niche artificial reefs. It is possible that such reefs will become a promising option for increasing fishing resources in areas weakened by overfishing or areas of small-scale fishing, favouring a return to activities linked to small-scale aquaculture. Thus, the NTAR structures may be used to recover and repair habitats damaged by anthropogenic intervention and also by climate changes.

\section{Abbreviations \\ AATN: Arrecifes artificiales tipo nicho; AMERB: Area de Manejo y Explotación de Recursos Bentónicos (Area of Benthic Resource Management and Exploitation); ANOSIM: Analysis of similarities; NMDS: Non-metric multidimensional scaling; NTAR: Niche-type artificial reef; SIMPER: Similarity percentage}

\section{Acknowledgements \\ The researchers wish to thank the Regional FONDEF for financing and support in carrying out project D13R20013 entitled "Development of niche artificial technology for the settling and recovery of red cusk-eels, Genypterus chilensis, aiming for sustainability of small-scale fishing in the Region of Bio Bio". We also gratefully acknowledge the collaboration of the following en- tities: the Regional Government of Bio Bio, the Undersecretary of Fishing and Aquaculture, the Municipality of Lebu, the Small-scale Fishing Trade Union Organisation of the Province of Arauco and the Dr Rigoberto Iglesias Bastáas Technical School.}

\section{Authors' contributions}

María-Isabel Toledo, Fishery Engineer and Aquaculture Doctor, developed the hypothesis of the research, analysed and made the discussion of the results and write and do the translation of the manuscript. Pamela Torres and Cristina Díaz are Marine Biologist; they did the monitoring, analysed the biological data and made the statistical analysis. Victor Zamora, Jesús López and Germán Olivares are Fisheries Engineers; they developed the reef design and the technology to anchor the reefs at the bottom of the sea. The authors read and approved the final manuscript. 


\section{Funding}

Funding of this project was obtained from Regional FONDEF

Program-National Scientific Technological Commission-CONICYT (Comisión Nacional Científico y Tecnológica). Currently: Agencia Nacional de Investigación y Desarrollo-ANID, Chile.

\section{Availability of data and materials}

All the material and data are presented in the manuscript.

\section{Ethics approval and consent to participate}

We give our consent to participate and ethics approval.

\section{Consent for publication}

The authors give their consent to publish this manuscript.

\section{Competing interests}

There is no competing of interest.

Received: 22 August 2019 Accepted: 1 July 2020

Published online: 21 July 2020

\section{References}

Andersson MH, Berggren M, Wilhelmsson D, Öhman M (2009) Epibenthic colonization of concrete and steel pilings in a cold-temperate embayment: a Weld experiment. Helgol Mar Res 63:249-260

Antoniadou C, Voultsiadou E, Chintiroglou C (2010) Seasonal patterns of colonization and early succession on sublittoral rocky cliffs. J Exp Mar Biol Ecol 403(1-2):21-30

Antoniadou C, Voultsiadou E, Chintiroglou C (2011) Benthic colonization and succession on temperate sublittoral rocky cliffs. J Exp Mar Biol Ecol 382(2): 145-153

Avila M, Malig R, Espinosa L, Piel M, Alcapan A, Villanueva F (2012) Guía ilustrada de fauna y flora asociada a praderas de luga roja y luga negra en áreas de manejo de la Región de los Lagos. Puerto Montt. Serie Programa Educativo Participativo para la Pesca Artesanal. II Biodiversidad en áreas de manejo. Universidad Arturo Prat 1-52 pp

Balqadi A, Salama AJ, Satheesh S (2018) Microfouling development on artificial substrates deployed in the central Red Sea. Oceanología 145. Article in Press, Corrected Proof. https://doi.org/10.1016/j.oceano.2017.10.006

Beserra AFB, Carloni GG, Carvalheira LV (2006) Colonization of Benthic Organisms on Different Artificial Substratum in Ilha Grande Bay, Rio de Janeiro, Brazil. Braz Arch Biol Technol 49(2):263-275

Birkeland C (1977) The importance of rate of biomass accumulation in early successional stages of benthic communities to the survival of coral recruits. In: Taylor DL (ed) Proceedings of Third International Coral Reef Symposium Vol. 1: Biology. Rosenstiel School of Marine and Atmospheric Science, Miami, pp 15-21

Brown KM, Swearingen DC (1998) Effects of seasonality, length of immersion, locality and predation on an intertidal fouling assemblage in the northern Gulf of Mexico. J Exp Mar Bio Ecol 225(1):107-121

Carter A, Prekel S (2008) Benthic colonization and ecological successional patterns on a planned nearshore artificial reef system in Broward County, SE Florida, Proceedings of the 11th International Coral Reef Symposium. Marine Science \& Biological Research Department, Boca Raton, pp 1210-1213

Choi CG, Jung SW, Ahn JK, Shimasaki Y, Kang IJ (2019) A study on Marine Algal Succession and Community in Pyramid-shaped Artificial Reef. J Fac Agric Kyushu Univ 64(1):95-99

Dean RL, Connell JH (1987a) Marine invertebrates in an algal succession. I. Variations in abundance and diversity with succession. J Exp Mar Biol Ecol 109:195-215

Dean RL, Connell JH (1987b) Marine invertebrates in an algal succession. III. Mechanisms linking habitat complexity with diversity. J Exp Mar Biol Ecol 109(3):249-273

Encarnação J, Calado G (2018) Effects of recreational diving on early colonization stages of an artificial reef in North-East Atlantic. J Coast Conserv 22(6):12091216

Fabi G, Spagnolo A, Bellan-Santini D, Charbonnel E, Çiçek BA, Goutayer García JJ, Jensen AC, Kallianiotis A, Neves dos Santos M (2011) Overview on Artificial Reefs in Europe. Braz J Oceanogr 59:155-166
Fariñas-Franco JM, Roberts D (2014) Early faunal successional patterns in artificial reefs used for restoration of impacted biogenic hábitats. Hydrobiologia 727(1):75-94

Firth LB, Thompson RC, Bohn K, Abbiati M, Airoldi L, Bouma TJ, Bozzeda F, Ceccherelli VU, Colangelo MA, Evans A, Ferrario F, Hanley ME, Hinz H, Hoggart SPG, Jackson JE, Moore P, Morgan EH, Perkol-Finkel S, Skov MW, Strain EM, van Belzen J, Hawkins SJ (2014) Between a rock and a hard place: Environmental and engineering considerations when designing coastal defence structures. Coast Eng 87:122-135

Foster MS, Harrold C, Hardin DD (1991) Point vs. photo quadrat estimates of the cover of sessile marine organisms. J Exp Mar Biol Ecol 146(2):193-203

Freckelton ML, Nedved BT, Hadfield MG (2017) Induction of Invertebrate Larval Settlement; Different Bacteria, Different Mechanisms? Sci Rep 7:42557. https://doi.org/10.1038/srep42557

Genzano GN, Meretta PE, Bremec C (2018) Macrobenthic colonization of the derelict Fisheries Vessel Khronometer, Cristo Rey Submarine Park, Argentina. Mar Ecol:e12491 https://doi.org/10.1111/maec.12491

Gonzalez-Duarte MM, Fernandez-Montblanc T, Bethencourt M, Izquierdo A (2018) Effects of substrata and environmental conditions on ecological succession on historic shipwrecks. Estuar Coast Shelf Sci 200:301-310

Henschel JR, Cook PA, Branch GM (1990) The colonization of artificial substrata by marine sessile organisms in False Bay. 1. Community development. Afr J Mar Sci 9(1):289-297

Herbert RJH, Collins K, Mallinson J, Hall AE, Pegg J, Ross K, Clarke L, Clements T (2017) Epibentic and mobile species colonisation of a geotextile artificial surf reef on the south coast of England. PLoS One 12(9):1-28

Higgins E, Scheibling RE, Desilets KM, Metaxas A (2019) Benthic community succession on artificial and natural coral reefs in the northern Gulf of Aqaba, Red Sea. PLoS ONE 14(2):1-24 https://doi.org/10.1371/journal.pone.0212842

Kendall MG (1955) Rank Correlation Methods, 2nd edn. Hafner Publishing Co, New York, p 196

Keough MJ (1998) Responses of settling invertebrate larvae to the presence of established recruits. J Exp Mar Biol Ecol 231(1):1-19

Komyakova V, Chamberlain D, Jones GP, Swearer SE (2019) Assessing the performance of artificial reefs as substitute hábitat for temperate reef fishes: Implications for reef design and placement. Sci Total Environ 668:139-152

Lavender JT, Dafforn KA, Bishop MJ, Johnston EL (2017) Small-scale habitat complexity of artificial turf influences the development of associated invertebrate assemblages. J Exp Mar Biol Ecol 492:105-112

Lee MO, Otakeb S, Kim JK (2018) Transition of artificial reefs (ARs) research and its prospects. Ocean Coast Manag 154:55-65

Lezzi M, del Pasqua M, Pierri C, Giangrande A (2018) Seasonal non-indigenous species succession in a marine macrofouling invertebrate community. Biol Invasions 20:937-961

Liu L, Du R, Zhang X, Dong S, Sun S (2017) Succession and seasonal variation in epilithic biofilms on artifi cial reefs in culture waters of the sea cucumber Apostichopus japonicus. Chin J Oceanol Limnol 35(1):132-152

Liversage K, Victoria C, Coleman R, McQuaid C (2017) Availability of microhabitats explains a widespread pattern and informs theory on ecological engineering of boulder reefs. J Exp Mar Biol Ecol 489:36-42

Lozano-Cortés DF, Zapata FA (2014) Invertebrate colonization on artificial substrates in a coral reef at Gorgona Island, Colombian Pacific Ocean. Rev Biol Trop 62(1):161-168

Margalef R (1958) Temporal succession and spatial heterogeneity in phytoplankton. In: Buzzati-Traverso AA (ed) Perspectives in Marine biology. University of California Press, Berkeley, pp 323-347

Martell L, Bracale R, Carrion SA, Purcell JE, Lezzi M, Gravili C, Piraino S, Boer F (2018) Successional dynamics of marine fouling hydroids (Cnidaria: Hydrozoa) at a finfish aquaculture facility in the Mediterranean Sea. PLoS ONE 13(4):118 https://doi.org/10.1371/journal.pone.0195352

Meyer KS, Brooke SD, Sweetman AK, Wolf M, Young CM (2017) Invertebrate communities on historical shipwrecks in the western Atlantic: relation to islands. Mar Ecol Prog Ser 566:17-29

Navarro-Barranco C, Guerra-García JM, Sanches-Tocino L, Ros M, Florido M, García-Gómez JC (2015) Colonization and successional patterns of the mobile epifaunal community along an environmental gradient in a marine cave. Mar Ecol Prog Ser 521:105-115

Noh J, Ryu J, Lee D, Khim JS (2017) Distribution characteristics of the fish assemblages to varying environmental conditions in artificial reefs of the Jeju Island, Korea. Mar Pollut Bull 118:388-396 
OSPAR Commission (2009) Assessment of construction or placement of artificial reefs. Biodiversity Series, Reino Unido, p 27

Pacheco AS, Laudien J, Thiel M, Oliva M, Heilmayer O (2011) Succession and seasonal onset of colonization in subtidal hard-bottom communities off northern Chile. Mar Ecol 32(1):75-87

Perkol-Finkel S, Benayahu Y (2005) Recruitment of benthic organisms onto a planned artificial reef shifts in community structure on decade post deployment. Mar Environ Res 59:79-99

Pielou EC (1975) Ecological Diversity. Wiley, New York, p 165

Ponti M, Fava F, Perlini RA, GiovaNTARdi O, Abbiati M (2015) Benthic assemblages on artificial reefs in the northwestern Adriatic Sea: Does structure type and age matter? Mar Environ Res 104:10-19

Rosental Zalmon I, Saleme de Sá F, Dornellas Neto EJ, de Rezende CE, Machado Mota P, Marques de Almeida TC (2014) Impacts of artificial reef spatial configuration on infaunal community structure - southeastern Brazil. J Exp Mar Biol Ecol 454:9-17

Salta M, Wharton JA, Blache Y, Stokes KR, Briand JF (2013) Marine biofilms on artificial surfaces: structure and dynamics. Environ Microbiol 15(11):2879-2893

Sen A, Podowski EL, Becker EL, Shearer EA, Gartman A, Yücel M, Hourdez S, Luther GW, Fisher CR (2014) Community succession in hydrothermal vent habitats of the Eastern Lau Spreading Center and Valu Fa Ridge, Tonga. Limnol Oceanogr 59(5):1510-1528

Shannon C (1948) A mathematical theory of communication. Bell Syst Tech J 27(3):379-423

Siboni N, Lidor M, Kramarsky-Winter E, Kushmaro A (2007) Conditioning film and initial biofilm formation on ceramics tiles in themarine environment. FEMS Microbiol Lett 274(1):24-29

Silva Lima J, Antunes Zappesc C, Madeira Di Benedittoa AP, Rosental Zalmon I (2018) Artisanalfisheries and artificial reefs on the southeast coast of Brazil Contributions to research and management. Ocean Coast Manag 163:372382

Spagnolo A, Cuicchi C, Punzo E, Santelli A, Scarcella G, Fabi G (2014) Patterns of colonization and succession of benthic assemblages in two artificial substrates. J Sea Res 88:78-86

Sweet MJ, Croquer A, Bythell JC (2011) Development of Bacterial Biofilms on Artificial Corals in Comparison to Surface-Associated Microbes of Hard Corals. PLOS ONE 6(6):e21195. https://doi.org/10.1371/journal.pone.0021195

Tapia L (2002) Guía de biodiversidad Vol. 1. macrofauna y algas marinas. №4: Algas. http://intranetua.uantof.cl/crea/guia\%20algas\%20.pdf. Reviewed: 25 January 2018

Toledo MI, Olivares G, Zamora V, Torres P, Díaz C, Herrera MJ (2017) Manual de construcción y manejo de nichos artificiales para el congrio colorado. Escuela de Ciencias del Mar. Pontificia Universidad Católica de Valparaíso, Valparaíso, p 68 ISBN 978-956-368-646-3

Uribe RA, Ortiz M, Macaya EC, Pacheco AS (2015) Successional patterns of hardbottom macrobenthic communities at kelp bed (Lessonia trabeculata) and barren ground sublittoral systems. J Exp Mar Biol Ecol 472:180-188

Vaz-Pinto F, Torrontegi O, Prestes ACL, Álvaro NV, Neto Al, Martins GM (2014) Invasion success and development of benthic assemblages: effect of timing, duration of submersion and substrate type. Mar Environ Res 94:72-79

Vergara J, Hernández A, Leal C, Palma E, Rudolph I (2016) Estudio de situación base AMERB Lebu. Informe Técnico, p 75

Xu M, Qi L, Zhang L, Zhang T, Yang H, Zhang Y (2019) Ecosystem attributes of trophic models before and after construction of artificial oyster reefs using Ecopath. Aquac Environ Interact 11:111-127

Zagal CJ, Hermosilla C (2007) Guía de invertebrados del sur de Chile. Fantástico Sur Birding Ltda, Punta Arenas, p 134

Zar JH (1999) Biostatistical analysis. Prentice Hall, New Jersey, p 663

Zúñiga O (2002a) Guía de biodiversidad Vol. 1 macrofauna y algas marinas. №: Moluscos. http://intranetua.uantof.cl/crea/guia\%20moluscos.pdf. Reviewed: 25 January 2018

Zúñiga O (2002b) Guía de biodiversidad Vol. 1. macrofauna y algas marinas. N²: Crustáceos. http://svsch.ceachile.cl/e-Biblioteca/Documentos/Biodiversidad/2 002_Guia_de_Crustaceos.pdf. Reviewed: 25 January 2018.

\section{Publisher's Note}

Springer Nature remains neutral with regard to jurisdictional claims in published maps and institutional affiliations.

\section{Submit your manuscript to a SpringerOpen ${ }^{\odot}$ journal and benefit from:}

- Convenient online submission

- Rigorous peer review

- Open access: articles freely available online

- High visibility within the field

- Retaining the copyright to your article

Submit your next manuscript at $\boldsymbol{\nabla}$ springeropen.com 